\title{
Health-related quality of life measurement in asthma and chronic obstructive pulmonary disease: review of the 2009-2014 literature
}

\author{
Fabio Arpinelli ${ }^{*}$, Mauro Carone ${ }^{2}$, Gioacchino Riccardo ${ }^{1}$ and Giorgio Bertolotti ${ }^{3}$
}

\begin{abstract}
Background: Asthma and chronic obstructive pulmonary disease (COPD) are frequent in the general population. These diseases can worsen the quality of life of people suffering from them, limiting their daily activities and disrupting their sleep at night. Some questionnaires to measure the impact of the diseases on the daily life of patients are available. The measurements of subjective outcomes have become a part of clinical practice, and are used very frequently in clinical trials. Our aim was to describe how data on HRQoL in asthma and COPD are reported in papers published in the medical literature.
\end{abstract}

Methods: We identified papers on the recent respiratory drugs (chemical, not biological), that reported the HRQoL measurement and that were published from 2009 to April 2014. We planned to describe data about HRQoL, and we had no intention of comparing the degree of efficacy of drugs.

Results: The most used questionnaires are the Asthma Quality of Life Questionnaire (AQLQ) and the Saint George's Respiratory Questionnaire (SGRQ). These tools, administered at the baseline and at the end of the study (and interim evaluations in the longer studies) allowed for the identification of improvements as perceived by the patient after the treatment, even if in some cases these improvements were limited and not clinically relevant. Subjective measurements have always been placed among the secondary endpoints and the number of patients (estimated for the main endpoint) has often statistically overestimated the result. In addition, it is clear that subjective data is normally reported, but rarely commented on.

Conclusions: There are some methodology aspects that should be discussed in more depth, for example the necessity to express variations in the subjective perception, not as $p$-value but as effect-size.

Keywords: Asthma, COPD, Asthma quality of life questionnaire, Health-related quality of life, Saint George's respiratory questionnaire

\section{Background}

Asthma and chronic obstructive pulmonary disease (COPD) are frequent in the general population. The prevalence of asthma is estimated to be between 1 and $18 \%$ of the population in the countries where it has been studied [1], whereas COPD affects about $6 \%$ of the adult population, with a higher prevalence in older age groups [2]. These diseases are characterised by a narrowing of the

* Correspondence: fabio.a.arpinelli@gsk.com

${ }^{1}$ GSK Medical and Scientific Department, Verona, Italy

Full list of author information is available at the end of the article bronchi associated with chronic inflammation. However, there are some differences between asthma and COPD in terms of onset age, causal factors, clinical aspects and impact on daily life. Functional measurements are used to measure severity and reversibility of the pulmonary obstruction. However, the relationship between pulmonary obstruction, dyspnea and impact of the disease on the daily life of the patient, is not necessarily linear [3]. The subjective data obtained from the patients can be useful for supplementing clinical and instrumental data and enabling the physician to identify any change (improvements 
or worsening) in the state of health, as perceived by the patient, thus allowing for an adjustment of the treatment. Questionnaires do exist and have been used for decades as they can gather data, in a standardised form, about the patients' perception of the status of the disease and/or the received medical treatments. This information, reported directly by the patient without other people's interpretation, about his/her well-being, behaviour and feelings as regards his/her state of health and the related treatments, is defined as Patient-Reported Outcome (PRO) [4]. The Health-related Quality of Life (HRQoL) is a well known PRO. We have had available for some time questionnaires that are used for measuring HRQoL. European and USA regulatory authorities have published official guidance documents that reflect their position on this topic. The USA Food and Drug Administration (FDA) prepared a formal "Guidance for Industry" which describes its position on the PROs and informs the pharmaceutical industry on how it intends to review and evaluate the PRO tools that are used to support label claims [5]. The European Medicine Agency (EMA) document points out the role that the HRQoL may play in the development process of a medicinal product, by simply providing some recommendations on their use [6]. Recently, a number of new medicinal products to be used alone or in fixed combinations have been registered for the treatment of asthma and/or COPD. In many clinical studies of these drugs, HRQoL measurements were included.

Our aim was to deepen the knowledge on how the measurement of HRQoL was carried out for supporting the registration of these drugs (medicinal products of chemical and not biological origin). We planned to review the papers in order to describe and comment on the used tools, the results of the measurements and the use of the HRQoL data that were obtained. We had no intention to comment on the degree of efficacy of the medicinal products being considered.

\section{Review}

We took into consideration the respiratory drugs that were launched in the last years. We described randomised and controlled clinical trials of medicinal products developed for asthma and for COPD, published from 2009 to the spring of 2014. The year 2009 was chosen because in that year the National Health Service in England (NHS) made the decision to measure the impact, as perceived by the patient, of some therapeutic procedures [7]. Non-randomised studies, post-hoc analyses, meta-analyses and/or systematic reviews of respiratory medicinal products have not been taken into account. For each study, the design, sample size, use of tools for the measurement of PROs have been identified and the related data briefly described. No statistical analyses of any type were carried out; in fact this report consists exclusively in a description of the findings.

Thirty four articles, published in the considered period, were analysed (see Tables 1 and 2). Eleven studies were on asthma. The questionnaire used in these studies was the Asthma Quality of Life questionnaire (AQLQ). The AQLQ is a 32 items questionnaire in 4 domains (symptoms, activity limitation, emotional function and environmental stimuli). It is suitable for adult with asthma, that should respond on a 7 point scale. Psychometric tests show that a change in score of 0.5 is the smallest change that can be considered clinically important (this means that the patient appreciates the change in his/her health condition).

Twenty three studies were on COPD. The questionnaire they used was the Saint George's Respiratory Questionnaire (SGRQ). It is a 50 items questionnaire designed to measure impact on overall health, daily life and perceived well-being in patients with COPD. Higher scores indicate more limitations. A mean change score of -4 units is considered as clinically important.

Only 3 studies on asthma reported a change that was statistically significant ( $27 \%$ of the studies), and only 2 (18\% of the studies) reported the percentage of patients who reached the clinical significance (at least 0.5 change from baseline). The clinical significance ranged between 55.0 and $66.7 \%$ of patients. Among studies on COPD, $16(69.5 \%)$ reported a statistical significance and 17 $(80 \%)$ reported the percentage of patients with the clinical significance (at least -4 units from baseline). The clinical significance ranged between 21.9 and $59.4 \%$ of patients.

Usually, the authors describe in a very short way HRQoL results, and poor details are reported.

\section{Conclusions}

A description of the literature about respiratory, nonbiological medicinal products, developed in the past few years, has allowed to highlight that the PRO measurement has been often included in the studies' protocols. This is in line with the recognition by regulatory authorities, payers and pharmaceutical companies that measurement of the patient experience with the drug is increasingly important. In all the measurements observed, the subjective data was considered a secondary endpoint. This is consistent with the endpoint hierarchy established by EMA and the FDA which sees the physiological effect produced by the study drug as a priority, and relegates the PRO to a secondary endpoint.

The choice of tools to be used meets the specifications of the reference documents. AQLQ is used with the patients with asthma, whereas the SGRQ is used with the patients with COPD. Both tools have been well documented since their initial development, and are 
Table 1 Studies on asthma

\begin{tabular}{|c|c|c|c|c|c|}
\hline Drugs & Baseline & Final score & Statistical significance ${ }^{a}$ & Clinical significance & Reference \\
\hline flut/form 500/20 $\mu \mathrm{g}$ & $4.42 \pm 0.89$ & $5.34 \pm 1.07$ & \multirow[t]{2}{*}{$P=0.036$} & & \multirow{2}{*}{$\begin{array}{l}\text { Bodzenta-Lukaszyk et al. } \\
\text { Resp Med } 105 \text { 674-682 } \\
2011 \text { [13] }\end{array}$} \\
\hline flut + form $500+24 \mu \mathrm{g}$ & $4.57 \pm 0.99$ & $5.30 \pm 1.00$ & & & \\
\hline flut/form250/10 $\mu \mathrm{g}$ & \multirow[t]{2}{*}{ Not reported } & \multirow{2}{*}{$\begin{array}{l}\text { Mean improvement of } 0.8 \\
\text { in both treatment groups }\end{array}$} & \multirow[t]{2}{*}{ ns } & $55 \%$ & \multirow{2}{*}{$\begin{array}{l}\text { Bodzenta-Lukaszyk et a.l } \\
\text { Journal of Asthma 49(10), } \\
\text { 1060-1070, } 2012 \text { [14] }\end{array}$} \\
\hline bud/form400/12 $\mu \mathrm{g}$ & & & & $57.6 \% \mathrm{~ns}$ & \\
\hline flut/form combo & $4.8 \pm 1.1$ & $5.5 \pm 1.1$ & \multirow[t]{2}{*}{ ns } & Not available & \multirow{2}{*}{$\begin{array}{l}\text { Bodzenta-Lukaszyk et al. } \\
\text { Current Medical Research } \\
\text { and Opinion 29, } 5 \text { 579-588, } \\
2013 \text { [15] }\end{array}$} \\
\hline flut + form & $4.9 \pm 1.2$ & $5.6 \pm 1.0$ & & & \\
\hline Tio $5 \mu \mathrm{g}$ add on & \multirow[t]{4}{*}{4.8 in all groups } & \multirow{4}{*}{$\begin{array}{l}\text { Change of } 0.1 \text { points for } \\
\text { both active treatments } \\
\text { compared with placebo }\end{array}$} & \multirow[t]{3}{*}{ ns } & \multirow[t]{3}{*}{ Not available } & \multirow{3}{*}{$\begin{array}{l}\text { Kerstjens et al. Journal of } \\
\text { Allergy Clin Immunol 128, } \\
2 \text { 308-314, } 2011 \text { [16] }\end{array}$} \\
\hline Tio $10 \mu \mathrm{g}$ add on & & & & & \\
\hline Plac add on & & & & & \\
\hline Trial 1 & & & & \multirow[t]{6}{*}{ Not achieved } & \multirow{6}{*}{$\begin{array}{l}\text { Kerstjens et al. New England } \\
\text { Journal of Medicine } \\
367: 1198-1207,2012 \text { [17] }\end{array}$} \\
\hline Tio $5 \mu \mathrm{g} /$ die add on & $4.6 \pm 1.1$ & 5.15 & Ns & & \\
\hline plac add on & $4.6 \pm 1.1$ & 5.1 & \multirow[t]{4}{*}{ Ns $(p<0.05$ al week 24} & & \\
\hline Trial 2 & & & & & \\
\hline Tio $5 \mu \mathrm{g} / \mathrm{die}$ add on & $4.6 \pm 1.0$ & 5.1 & & & \\
\hline plac add on & $4.7 \pm 1.1$ & 4.93 & & & \\
\hline Bud/formSMART & 4.78 & 4.81 & \multirow[t]{2}{*}{ ns } & \multirow{2}{*}{$\begin{array}{l}\text { Not available - } \\
\text { measurement } \\
\text { of Satisfaction with } \\
\text { Asthma Treatment } \\
\text { Questionnaire }\end{array}$} & \multirow{2}{*}{$\begin{array}{l}\text { Louis R et al. The International } \\
\text { Journal of Clinical Practice 63, } \\
10 \text { 1479-1488, } 2009 \text { [18] }\end{array}$} \\
\hline Conventional best practice & 4.78 & 4.82 & & & \\
\hline Tio & & 5.58 & $P=0.01$ & \multirow[t]{3}{*}{ Not available } & \multirow{3}{*}{$\begin{array}{l}\text { Peters et al. New England } \\
\text { Journal of Medicine } 363 \\
18 \text { 1715-1726, } 2010 \text { [19] }\end{array}$} \\
\hline Double glucocorticoid & \multirow[t]{2}{*}{$5.43 \pm 1.05$} & 5.48 & $P=0.38$ & & \\
\hline salm & & 5.71 & $P<0.001$ & & \\
\hline Flut fur/vil 200/25 $\mu \mathrm{g}$ & \multirow[t]{3}{*}{ Not available } & Baseline + $0.93 \pm 0.065$ & \multirow[t]{3}{*}{ ns } & \multirow[t]{3}{*}{ Not available } & \multirow{3}{*}{$\begin{array}{l}\text { O'Byrne et al. Eur. Resp. } \\
\text { Journal } 43 \text { 773-782, } \\
2014 \text { [20] }\end{array}$} \\
\hline Flut fur.200 $\mu \mathrm{g}$ & & Baseline + $0.88 \pm 0.071$ & & & \\
\hline Flut prop.500 $\mu \mathrm{g}$ & & Baseline $+0.90 \pm 0.068$ & & & \\
\hline Flut. fur/vil 100/25 $\mu \mathrm{g}$ & 5.35 & 5.85 & \multirow[t]{2}{*}{ ns } & $46 \%$ & \multirow{2}{*}{$\begin{array}{l}\text { Woodcock et al. Chest 144(4), } \\
\text { 1222-1229, } 2013 \text { [21] }\end{array}$} \\
\hline flut. pro/salm 250/50 $\mu \mathrm{g}$ & 5.37 & 5.79 & & $38 \%$ & \\
\hline salm $50 \mu \mathrm{g}$ & 5.175 & Baseline +0.280 & ns & Not available & Bateman et al. J. Allergy Clin \\
\hline tio $5 \mu \mathrm{g}$ & & Baseline +0.131 & & & $\begin{array}{l}\text { Immunol128, 315-322, } \\
2011[22]\end{array}$ \\
\hline plac & & Baseline +0.039 & & Not available & \\
\hline Adjustable bud/form & AQLQ & AQLQ & AQLQ & AQLQ & O'Connor et al. Journal of \\
\hline Fixed bud/form & Not available & Not available & $P<0.04^{*}$ & $66.7 \%$ & $\begin{array}{l}\text { Asthma } 47 \text { 217-223, } \\
2010[10]\end{array}$ \\
\hline Adjustable bud/form & & & $\mathrm{Ns}^{\mathrm{b}}$ & $63.0 \%$ & \\
\hline & & & & $61.9 \%$ & \\
\hline & & & & $\begin{array}{l}\text { No clinical difference } \\
\text { between groups }\end{array}$ & \\
\hline
\end{tabular}

${ }^{\mathrm{a}}$ Between groups

${ }^{\mathrm{b}}$ Fixed-dose regimen baseline vs end of treatment

*Adjustable dosing vs fixed dose regimen

$p \leq 0.002$ vs fluticasone propionate/salmeterol

validated and available in many languages $[8,9]$. In all the studies, the time frame for the administration of the questionnaires is specified. In the shorter studies, the measurements are reported at the baseline and at the end of the study. In longer studies, there can be interim measurements. It should be noted that the short duration of a study (in particular in the COPD case) is planned to allow for functional measurements, but it could not capture the impact that the drug has on the health, as perceived by the patient. For instance, Kerwin 
Table 2 Studies on COPD

\begin{tabular}{|c|c|c|c|c|c|}
\hline Drugs & Baseline SGRQ & Final score & Statistical significance ${ }^{a}$ & Clinical significance & Reference \\
\hline Aclid $200 \mu \mathrm{g}$ & 45.9 & -4.7 vs baseline & $P=0.013$ vs plac. & $49 \% *$ & \multirow{3}{*}{$\begin{array}{l}\text { Kerwin E.M., et al. COPD } \\
\text { patients (ACCORD COPD I). } \\
\text { COPD } 9 \text { 90-101, } 2012 \text { [23] }\end{array}$} \\
\hline Aclid $400 \mu \mathrm{g}$ & 48.3 & -4.5 vs baseline & \multirow[t]{2}{*}{$P=0.019$ vs plac. } & $45 \%$ & \\
\hline plac & 45.1 & - 2 vs baseline & & $36 \%$ & \\
\hline Aclid $200 \mu \mathrm{g}$ & $46.3 \pm 16.8$ & $-3.8 \pm 1.1$ vs plac & $P<0.001$ vs plac & $56.0 \% * *$ & \multirow{3}{*}{$\begin{array}{l}\text { Jones P.W., et al. Eur Resp } \\
\text { Journal } 40 \text { 830-836, } 2012 \text { [11] }\end{array}$} \\
\hline Aclid $400 \mu \mathrm{g}$ & $47.6 \pm 17.7$ & $-4.6 \pm 1.1$ & $P<0.0001$ vs & $57.3 \% * *$ & \\
\hline plac & $45.1 \pm 15.8$ & & plac. & $41.0 \%$ & \\
\hline Aclid $200 \mu \mathrm{g}$ & 48.5 & -5.3 vs baseline & \multirow[t]{2}{*}{ ns } & $41-6 \%-46.6 \%$ & \multirow{2}{*}{$\begin{array}{l}\text { Gelb A.F., et al. Respiratory } \\
\text { Medicine } 107 \text { 1957-1965, } \\
2013 \text { [24] }\end{array}$} \\
\hline Aclid $400 \mu \mathrm{g}$ & 49.8 & -5.2 vs baseline & & $45.2 \%-49.1 \%$ & \\
\hline Glycopyr 50 mg & 46.11 & 39.50 & \multirow[t]{3}{*}{$P=0.004$} & $56.8 \%$ & \multirow{3}{*}{$\begin{array}{l}\text { D'Urzo A., et al. Respiratory } \\
\text { Research } 12 \text { 156, } 2011 \text { [25] }\end{array}$} \\
\hline \multirow[t]{2}{*}{ Plac } & \multirow[t]{2}{*}{46.34} & \multirow[t]{2}{*}{42.31} & & $46.3 \%$ & \\
\hline & & & & $P=0.006$ & \\
\hline Glycopyr 50 g & Not & -3.32 vs placebo & $P<0.001$ & $54.3 \%$ & \multirow{3}{*}{$\begin{array}{l}\text { Kerwin E., at al. European } \\
\text { Respiratory Journal } 40 \\
1106-1114,2012 \text { [26] }\end{array}$} \\
\hline Tio $18 \mu \mathrm{g}$ & reported & -2.84 vs placebo & $P=0.014$ & $59.4 \%$ & \\
\hline Plac & & & & $50.8 \%$ & \\
\hline Indac $300 \mu \mathrm{g}$ & 43 & -4.7 vs placebo & \multirow[t]{4}{*}{$P<0.001$ vs plac } & Not reported & \multirow{4}{*}{$\begin{array}{l}\text { Dahl R. et al. Thorax } 65 \\
473-479,2010 \text { [27] }\end{array}$} \\
\hline Indac $600 \mu \mathrm{g}$ & 44 & -4.6 vs placebo & & & \\
\hline Form & 44 & \multirow[t]{2}{*}{-4.0 vs placebo } & & & \\
\hline Plac & 43 & & & & \\
\hline Indac $150 \mu \mathrm{g}$ & $43 \pm 18.6$ & -5.0 vs baseline & $P<0.001$ & $52.8 \% \%^{* *}$ & Kornmann O. et al. European \\
\hline Salm $50 \mu \mathrm{g}$ & 44. \pm 18.4 & -4.1 vs baseline & $P<0.001$ & $48.6 \% * * *$ & $\begin{array}{l}\text { Respiratory Journal 3/ 2/3-2/9, } \\
2011 \text { [28] }\end{array}$ \\
\hline plac & $44 \pm 18.1$ & & & $38.0 \%$ & \\
\hline Indac $150 \mu \mathrm{g}$ & \multirow[t]{4}{*}{ Not reported } & -3.3 vs placebo ${ }^{* * * *}$ & $P<0.001$ vs plac & - & \multirow{4}{*}{$\begin{array}{l}\text { Donohue J.F. et al. Am J Respir } \\
\text { Crit Care Med } 182 \text { 155-162, } \\
2010 \text { [29] }\end{array}$} \\
\hline Indac $300 \mu \mathrm{g}$ & & -2.4 vs placebo & $P<0.01$ vs plac & & \\
\hline Tio $18 \mu \mathrm{g}$ & & -1.0 vs placebo & Ns vs plac & & \\
\hline \multicolumn{4}{|l|}{ plac } & & \\
\hline Indac $150 \mu \mathrm{g}$ & $42.3 \pm 17.60$ & $37.1 \pm 0.56$ & \multirow[t]{3}{*}{$P<0.001$} & $50.5 \%$ & \multirow{3}{*}{$\begin{array}{l}\text { Buhl R. et al. Eur Respir J } 38 \\
\text { 797-803, } 2011 \text { [30] }\end{array}$} \\
\hline \multirow[t]{2}{*}{ Tio $18 \mu \mathrm{g}$} & \multirow[t]{2}{*}{$42.7 \pm 18.04$} & \multirow[t]{2}{*}{$39.2 \pm 0.55$} & & $42.5 \%$ & \\
\hline & & & & $p \leq 0.001$ & \\
\hline Indac $150 \mu \mathrm{g}$ & 47.9 & 42.3 & \multirow[t]{2}{*}{$P=0.73$} & $49 \%$ & \multirow{2}{*}{$\begin{array}{l}\text { Decramer M.L. et al. Lancet } \\
\text { Respir Med } 1 \text { 524-533, } 2013 \text { [31] }\end{array}$} \\
\hline Tio $18 \mu \mathrm{g}$ & 48.7 & 42.2 & & $49 \&$ & \\
\hline Tio $5 \mu \mathrm{g}$ & Not reported & -4.7 vs baseline & $P<0.0001$ & $49.5 \%$ & Bateman E.D. et al. Respiratory \\
\hline P lac & & -1.8 vs baseline & & $41.4 \%$ & $\begin{array}{l}\text { Mearcine 104, } 1460-14 / 2, \\
2010 \text { [32] }\end{array}$ \\
\hline & & & & $P<0.0001$ & \\
\hline Tio 18 mg emphysema & $46.7 \pm 3.0$ & $39.4 \pm 2.7$ & ns & Not reported & Fujimoto K. et al. International \\
\hline Tio $18 \mu \mathrm{g}$ non emphys & $35.1 \pm 6.4$ & $26.9 \pm 4.6$ & & & 2011 [33] \\
\hline Salm 50 mg emphysema & $38.6 \pm 3.5$ & $33.0 \pm 3.2$ & & & \\
\hline Salm $50 \mu \mathrm{g}$ nonemphys & $37.5 \pm 8.5$ & $29.3 \pm 7.4$ & & & \\
\hline Tio $18 \mu \mathrm{g}$ & $46.1 \pm 19.1$ & -4.5 vs baseline & $P<0.05$ & Not reported & Hoshino M. et al Respirology 16 \\
\hline Tio + Salm/flut 50/250 $\mu \mathrm{g}$ & $42.7 \pm 17.0$ & -10.2 vs baseline & & & 9 \\
\hline Umec $62.5 \mu \mathrm{g}$ & Not reported & -3.14 vs baseline & $P<0.001$ both doses of & Not reported & Trivedi R. et al. Eur Respiratory J \\
\hline Umec $125 \mu \mathrm{g}$ & & -6.12 vs baseline & & & \\
\hline Plac & & +4.75 vs baseline & & & \\
\hline Beclom/form 100/6 $\mu \mathrm{g}$ & $60.4 \pm 19.5$ & $-3.75 \pm 13.91$ & ns & $25.40 \%$ & \\
\hline Bud/form 200/6 $\mu \mathrm{g}$ & $57.2 \pm 18.6$ & $-4.28 \pm 11.92$ & & $21.90 \%$ & \\
\hline
\end{tabular}


Table 2 Studies on COPD (Continued)

\begin{tabular}{|c|c|c|c|c|c|}
\hline Form $12 \mu \mathrm{g}$ & $59.5 \pm 20.2$ & $-2.90 \pm 13.28$ & & $25.30 \%$ & $\begin{array}{l}\text { Calverley P.M.A. et al. Respiratory } \\
\text { Medicine } 104 \text { 1858-1868, } \\
2010 \text { [36] }\end{array}$ \\
\hline Tio + bud/form & \multirow[t]{3}{*}{ Not reported } & -3.8 vs baseline & \multirow[t]{3}{*}{$P=0.023$} & $49.5 \%$ & \multirow{3}{*}{$\begin{array}{l}\text { Welte T. et al. Am J Respir Crit } \\
\text { Care Med } 180741-750,2009 \text { [37] }\end{array}$} \\
\hline \multirow[t]{2}{*}{ Tio + plac } & & -1.5 vs baseline & & $40.0 \%$ & \\
\hline & & & & $P=0.016$ & \\
\hline Bud/form 320/9 $\mu \mathrm{g}$ & $55.9(17.6)$ & $-7.2(1.18)$ vs bas. & \multirow[t]{3}{*}{ ns } & & \multirow{3}{*}{$\begin{array}{l}\text { Sharafkhaneh A. et al. Respiratory } \\
\text { Medicine 106, 2257-268 } 2012 \text { [38] }\end{array}$} \\
\hline Bud/form 160/9 $\mu \mathrm{g}$ & $57.8(16.7)$ & $-5.5(1.17)$ vs bas. & & & \\
\hline Form $9 \mu \mathrm{g}$ & $58.6(16.9)$ & $-5.9(1.17)$ vs bas. & & & \\
\hline $\begin{array}{l}\text { Indac/Glycopyr } \\
110 / 50 \mu \mathrm{g}\end{array}$ & 42.01 & 35.45 & \multirow[t]{2}{*}{ ns } & $55.5 \%$ & \multirow[t]{2}{*}{$\begin{array}{l}\text { Vogelmeier C.F. et al. Lancet } \\
\text { Respir Med 1 51-60, } 2013 \text { [39] }\end{array}$} \\
\hline Salm/flut 50/500 $\mu \mathrm{g}$ & 42.72 & 36.68 & & $49.1 \%$ & \\
\hline $\begin{array}{l}\text { Indat/Glycopyr } \\
110 / 50 \mu \mathrm{g}\end{array}$ & $53(18)$ & 43.8 & glycop/indacat & $57 \%$ & \multirow[t]{4}{*}{$\begin{array}{l}\text { Wedzicha J.A. et al. Lancet Respir } \\
\text { Med } 1 \text { 199-209, } 2013 \text { [40] }\end{array}$} \\
\hline Glycopyr $50 \mu \mathrm{g}$ & $52(18)$ & 45.8 & $P=0.0067 \mathrm{e}$ & $52 \%$ & \\
\hline \multirow[t]{2}{*}{ Tio $18 \mu \mathrm{g}$} & \multirow[t]{2}{*}{$52(17)$} & 46.0 & \multirow[t]{2}{*}{$P=0.00037$ vs competitors } & $51 \%$ & \\
\hline & & & & $\begin{array}{l}\text { Glycopir/indacat } \\
p=0.055 \text { e } p=0.051 \\
\text { vs competitors }\end{array}$ & \\
\hline $\begin{array}{l}\text { Indac } 150 \mu \mathrm{g}+\text { Glycopyr } \\
50 \mu \mathrm{g}\end{array}$ & \multirow[t]{2}{*}{ Not reported } & $-6.22(11.47)$ & \multirow[t]{2}{*}{ ns } & $56.5 \%$ & \multirow[t]{2}{*}{$\begin{array}{l}\text { Vincken W. et al. Int Journal of } \\
\text { COPD } 9 \text { 215-228, } 2014 \text { [41] }\end{array}$} \\
\hline Indac $150 \mu \mathrm{g}$ & & $\begin{array}{l}-4.13(10.38) \text { vs } \\
\text { baseline }\end{array}$ & & $46.8 \% \mathrm{~ns}$ & \\
\hline Beclom/form 200/12 $\mu \mathrm{g}$ & $47.0(16.7)$ & -5.92 & \multirow[t]{3}{*}{$P=0.08$} & $45.0 \%$ & \multirow{3}{*}{$\begin{array}{l}\text { Singh D. et al. BMC Pulmonary } \\
\text { Medicine } 14432014 \text { [42] }\end{array}$} \\
\hline \multirow[t]{2}{*}{ Flutic/salm 500/50 $\mu \mathrm{g}$} & \multirow[t]{2}{*}{$45.2(16.5)$} & \multirow[t]{2}{*}{-3.80} & & $36.2 \%$ & \\
\hline & & & & ns & \\
\hline Umec/Vil 62.5/25 $\mu \mathrm{g}$ & \multirow[t]{4}{*}{ Not reported } & $-8.07(0.749)$ & $p \leq 0.001$ vs & $49 \%$ & \multirow{4}{*}{$\begin{array}{l}\text { Donohue J.F. et al. Respiratory } \\
\text { Medicine } 107 \text { 1538-1546, } \\
2013 \text { [43] }\end{array}$} \\
\hline Umec $62.5 \mu \mathrm{g}$ & & $-7.25(0.753)$ & \multirow[t]{3}{*}{ placebo } & $44 \%$ & \\
\hline Vil25 $\mu \mathrm{g}$ & & $-7.75(0.760)$ & & $48 \%$ & \\
\hline Plac & & $\begin{array}{l}-2.56(0.950) \text { vs } \\
\text { baseline }\end{array}$ & & $34 \%$ & \\
\hline 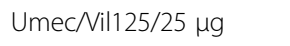 & \multirow[t]{4}{*}{ Not reported } & $40.10(0.665)$ & Combination & $49 \%$ & \multirow{4}{*}{$\begin{array}{l}\text { Celli B. et al Chest } 145 \text { (5) } \\
981-991,2014[44]\end{array}$} \\
\hline Umec125 $\mu \mathrm{g}$ & & $43.38(0.664)$ & $p \leq 0.001$ vs umec $e$ & $40 \%$ & \\
\hline Vil $25 \mu \mathrm{g}$ & & $42.82(0.681)$ & $p<0.01$ vs & $41 \%$ & \\
\hline Plac & & $43.69(0.875)$ & vilanterol & $37 \%$ & \\
\hline
\end{tabular}

reports, in the conclusions of his study, that a duration above 12 weeks could have allowed the patients treated with aclidinium $400 \mu \mathrm{g}$ to reach the Minimal Clinical Important Difference (MCID) in a significantly greater percentage compared with the patients receiving placebo [10]. A further aspect for consideration is the use of the placebo treatment arm. These patients may receive rescue treatment, and often the variation in the SGRQ score obtained with these patients is important, as is the percentage of responder patients (those who reach the MCID). Another aspect noted in some studies was that the improvement reported with the SGRQ was in contrast with the bronchodilator effect. For example, Jones et al point out this aspect in the placebo arm of their study where the spirometry values decline, but the patients report a better respiratory state of health [11].

The measurements are always accompanied by information on their statistical significance. With reference to this point, we noted that more COPD than asthma studies reported a statistical significance. In other words, it seems that COPD drugs are significantly more effective than asthma drugs. Furthermore, it is to 
consider that a number of COPD studies foresaw the analysis versus a placebo arm, and the number of patients could be excessive for the HRQoL measurement. With reference to the clinical significance, asthma patients have a higher percentage of patients who experienced a clinically important change than COPD patients (despite the lower number of measurements). We can speculate that asthma patients perceive better the changes given by drugs than COPD patients. On the other hand, asthmatics are generally younger than COPD patients, and suffer less from other diseases (comorbidities). However, the subjective nature of the measurements should lead to some considerations on the significance of the effects produced by the treatment. Usually, the variations in the scores obtained from the questionnaires on HRQoL are assessed on an effect-size basis, since a change produced by a treatment may be statistically significant (possibly because the number of patients calculated for the main endpoint is high), but it may not be perceived as clinically significant by the patients. In general, effect-size indexes have been developed for the exact purpose to avoid making incorrect inferences, due also to high sample sizes. In other words, since the above indicated indexes seek to square the results net of the effects of the sample (number of subjects), they should not be affected by this data. The effect-size indexes allow for an evaluation of the amplitude of an effect in each research design, but there always remains the difficulty of choosing the most appropriate index and interpreting the results. Perhaps the latter is the reason why measurement results are usually reported without comments. In some cases, PRO measurement data are included in the discussion, but in many other cases, they are only briefly mentioned.

Undoubtedly, the PRO adds knowledge to the drug. Within the respiratory area, there are many medicinal products available which have demonstrated their efficacy in intervening on the two main characteristics that define asthma and COPD, i.e. bronchoconstriction and chronic inflammation. However, only some of them provide information about the outcomes of treatment which may be important to patients. This data could represent a discriminatory factor in the choice of the medicinal products to be included into a formulary. In fact, a medicinal product that is perceived as useful by the patient could have more probability to be taken (good adherence to treatment) and this would maximise the financial investment of the third party payer. Among the cited studies, one has used the Onset of Effect Questionnaire (OEQ) to measure the preference of the patient with asthma of a certain bronchodilator versus another bronchodilator in the same pharmacological category, but slower in manifesting its effects [10]. The fact that this questionnaire was not used in other studies may mean that it is not important to measure this parameter, or that the questionnaire was used in that study just to reiterate that one of the drugs was faster in manifesting its effects.

Some studies, not included in this analysis because they were published before 2009, measured the preferences of the patients regarding the inhaler used. Dalby et al cite these experiences in one article that discusses the development of an inhaler [12]. This measurement can be useful also if the intent is to provide the patient with a treatment, that, on average, he/she will consider satisfactory and therefore, presumably, be more willing to adopt.

To conclude, the subjective measurements, initially reserved for patients with very serious diseases and a limited life expectancy, have become more commonly used even with patients suffering from chronic diseases. The fact that patients with asthma and COPD can have a longer life expectancy makes the quality of those years left to live very important. It is therefore desirable that the PRO measurements be increasingly used and become part of the daily routine of clinical practice. In this perspective, tools such as the SGRQs might be considered labour-intensive requiring too long for their completion and interpretation. To this end, some other easier and simpler tools could be proposed for development.

\section{Abbreviations \\ AQLQ: Asthma Quality of Life questionnaire; COPD: chronic obstructive pulmonary disease; EMA: European Medicine Agency; FDA: Food and Drug Administration; HRQoL: Health-related Quality of Life; MCID: minimal clinical important difference; OEQ: onset of effect questionnaire; PRO: patient-reported outcome; SGRQ: Saint George's Respiratory Questionnaire.}

\section{Competing interest}

FA and GA: the authors declare to be members of the Medical Dept. of GSK Italy

MC and GBi: the authors declare that they have no competing interests.

This paper was prepared without any financial support. All authors gave their contribution without any compensation.

\section{Authors' contributions}

FA had the idea to review the literature and drafted the manuscript; GR found the papers and prepared the tables; MC and GB revised critically the manuscript and gave substantial contributions. All authors read and approved the final manuscript.

\section{Acknowledgments}

The authors wish to thank Maria Sandra Magnoni for her precious help in finding papers.

$F A$ and $G R$ wish to thank $M C$ and $G B$ for their participation in writing this manuscript without any fee.

\section{Author details}

${ }^{1}$ GSK Medical and Scientific Department, Verona, Italy. ${ }^{2}$ Fondazione Salvatore Maugeri, IRCCS, Pneumology Division, Cassano Murge, Italy. ${ }^{3}$ Fondazione Salvatore Maugeri, IRCCS, Psychology Service, Tradate, Italy.

Received: 15 October 2015 Accepted: 5 January 2016

Published: 15 February 2016 


\section{References}

1. Global Strategy for Asthma Management and Prevention (updated 2012) at www.ginasthma.org. Accessed 22 Apr 2014.

2. Global Strategy for the Diagnosis, Management and Prevention of Chronic Obstructive Pulmonary Disease (updated 2014) at www.goldcopd.org. Accessed 22 Apr 2014

3. Agusti A, Calverley P, Celli B, Coxson HA, Edwards LD, Lomas DA, et al. Characterisation of COPD heterogeneity in the ECLIPSE cohort. Respir Res. 2010;11:122

4. Patrick DL, Burke LB, Powers JN, Scott JA, Rock E.P., Dawisha S, et al. PatientReported Outcomes to support Medical Product Labelling claims: FDA perspective. Value Health. 2007;10(s2):125-37.

5. Guidance for Industry. Patient-Reported Outcome Measures: Use in Medical Products Development to Support Labeling Claims. Silver Spring, MD: US Department of Health and Human Services Food and Drug Administration 2009.

6. Reflection Paper on the Regulatory Guidance for the Use of Health-related Quality of Life Measures in the Evaluation of Medicinal Products.European Medical Agency 2005 at http://www.ema.europa.eu/docs/en_GB/document library/Scientific guideline/2009/09/WC500003637.pdf. Accessed 18 apr 2014.

7. Worth A, Hammersley VS, Nurmatov U, Sheikh A. Systematic literature review and evaluation of patient reported outcome measures (PROMs) for asthma and related allergic diseases. Prim Care Respir J. 2012;21(4):455-8.

8. Juniper EF, Buist AS, Cox FM, Ferrie PJ, King DR. Validation of a standardized version of the Asthma Quality of Life Questionnaire. Chest. 1999;1 15:1265-70.

9. Jones PW, Quirk FH, Baveystock CM, Littlejohns P. A self-complete measure of health status for chronic airflow limitation. The Saint George Respiratory Questionnaire. Am Rev Respir Dis. 1992;145:1321-7.

10. O'Connor RD, Patrick DL, Parasuraman B, Martin P, Goldman M. Comparison of Patient-reported outcomes during treatment with adjustable- and fixeddose budesonide/formoterol pressurized merered-dose inhaler versus fixeddose fluticasone propionate/salmeterol dry powder inhaler in patients with asthma. J Asthma. 2010;47:217-23.

11. Jones PW, Singh D, Bateman ED, Agusti A, Lamarca R, de Miquel G, et al. Efficacy and safety of twice-daily aclidinium bromide in COPD patients: the ATTAIN study. Eur Respir J. 2012:40:830-6.

12. Dalby RN, Eicher J, Zierenberg B. Development of Respimat Soft Mist Inhaler and its clinical utility in respiratory disorders. Med Devices Evid Res. 2011:4:145-55.

13. Bodzenta-Lukaszyk A, Pulka G, Dymec A, Bumbacea D, Mclver T, Schwab B, et al. Efficacy and safety of fluticasoene and formoterol in a single pressurized metered dose inhaler. Respir Med. 2011;105:674-82.

14. Bodzenta-Lukaszyk, Buhl R, Balint B, Lomax M, Spooner K, Dissanayake S. Fluticasone /formoterol combination therapy versus Budesonide/formoterol for the treatment of asthma: a randomized, controller, non-inferiority trial of efficay and safety. J Asthma. 2012;49(10):1060-70.

15. Bodzenta-Lukaszyk A, van Noord J, Schroder-Babo W, McAulay K, Mclver T. Efficacy and safety profile of fluticasone/formoterol combination therapy compared to its individual components administered concurrently in asthma: a randomised controller trial. Curr Med Res Opin. 2013;29(5):579-88.

16. Kerstjiens HAM, Disse B, Schroder-Babo W, Bantie TA, Gahlemann M, Sigmund $\mathrm{R}$, et al. Tiotropium improves lung function in patients with severe uncontrolled asthma: a randomized controlled trial. J Allerg Clin Immunol. 2011;128, 2:308-14.

17. Kerstjens HAM, Engel M, Dahl R, Paggiaro P, Beck E, Vanderwalker $M$, et al. Tiotropium in asthma poorly controlled with standard combination therapy. N Engl J Med. 2012;367:1198-207.

18. Louis R, Joos G, Michils A, Vandenhoven G. A comparison of budesonide/ formoterol maintenance and relieve therapy vs conventional best practice in asthma management. Int J Clin Pract. 2009;63 10:1479-88.

19. Peters SP, Kunselman SJ, Icitovic N, Moore WC, Pascual R, Ameredes BT, et al. Tiotropium bromide step-up therapy for adult with uncontrolled asthma. N Engl J Med. 2010;363 18:1715-26.

20. O'Byrne PM, Bleecker ER, Bateman ED, Busse WW, Woodcock A, Forth R, et al. Once-daily fluticasone furoate alone or combined with vilanterol in persistent asthma. Eur Respir J 2014;43:773-82.

21. Woodcock A, Bleecker ER, Lotvall J, O'Byrne PM, Bateman ED, Medley H et, et al. Efficacy and safety of fluticasone furoate/vilanterol compared with fluticasone propionate/salmeterol combination in adult and adolescent patients with persistent asthma. Chest. 2013;144(4):1222-9.

22. Bateman ED, Kornmann O, Schmidt P, Pivovarova A, Engel M, Fabbri LM. Tiotropium is noninferior to salmeterol in maintaining improved lung function in B16-Arg/Arg patients with asthma. J Allergy Clin Immunol. 2011; 128:315-22.
23. Kerwin EM, D'Urzo AD, Gelb AF, Lakkis H, Garcia Gil E, Caracta CF. Efficacy and safety of a 12-week treatment with twice-daily aclidinium bromide in COPD patients (ACCORD COPD I). COPD. 2012;9:90-101.

24. Gelb AF, Tashkin DP, Make BJ, Zhong X, Garcai Gil E, Caracta CF. Long-term safety and efficacy of twice-daily aclidinium bromide in patients with COPD. Respir Med. 2013;107:1957-65.

25. D'Urzo A, Ferguson GT, van Noord JA, Hirata K, Martin C, Lu Y, et al. Efficacy and safety of once-daily NVA237 in patients with moderate to severe COPD: the GLOW1 trial. Respir Res. 2011;12:156.

26. Kerwin E, Hebert J, Gallagher N, Martin C, Overend T, Alagappan VK, et al. Efficacy and safety of NVA237 versus placebo and tiotropium in patients with COPD: the GLOW2 study. Eur Respir J. 2012;40:1106-14.

27. Dahl R, Chung KF, Buhl R, Magnussen H, Nonikov V, Jack D, et al. Efficacy of a new once-daily long acting $\beta 2$ - agonist indacaterol versus twice-daily formoterol in COPD. Thorax. 2010;65:473-9.

28. Kornmann O, Dahl R, Centanni S, Dogra A, Owen R, Lassen C, et al. Oncedaily indacaterol versus twice-daily salmeterol for COPD: a placebocontrolled comparison. Eur Respir J. 2011;37:273-9.

29. Donohue JF, Fogarty C, Lotvall J, Mahler DA, Worth H, Yorgancioglu A, et al. Once-daily bronchodilators for chronic obstructive pulmonary disease. Indacaterol versus Tiotropium. Am J Respir Crit Care Med. 2010;182:155-62.

30. Buhl R, Dunn LJ, Disdier C, Lassen C, Amos C, Henley M, et al. Blinded 12week comparison of once-daily indacaterolo and tiotropium in COPD. Eur Respir J. 2011:38:797-803.

31. Decramer ML, Chapman KR, Dahl R, Frith P, Devouassoux G, Fritscher C, et al. Once-daily indacaterol versus tiotropium for patients with severe chronic obstructive pulmonary disease (INVIGORATE): a randomized, blinded parallel- group study. Lancet Respir Med. 2013;1:524-33.

32. Bateman ED, Tashkin D, Siafakas N, Dahl R, Towse L, Massey D, et al. A one year trial of tiotropium Respimat plus usual therapy in COPD patients. Respir Med. 2010;104:1460-72.

33. Fujimoto K, Kitaguchi Y, Kanda S, Urushihata K, Hanaoka M, Kubo K. Comparison of efficacy of long-acting bronchodilators in emphysema dominant and emphysema nondominant chronic obstructive pulmonary disease. Int J COPD. 2011;6:219-27.

34. Hoshino M, Ohtawa J. Effect of adding salmeterol/fluticasone propionate to tiotropium on airway dimensions in patients with chronic obstructive pulmonary disease. Respirology. 2011:16:95-101.

35. Trivedi R, Richard N, Metha R, Church A. Umeclidinium in patients with COPD: a randomized, placebo-controlled study. Eur Respir J. 2014;43:72-81.

36. Calverley PMA, Kuna P, Monso' E, Costantini M, Petruzzelli S, Sergio F, et al. Beclomethasone/formoterol in the management of COPD: a randomized controlled trial. Respir Med. 2010;104:1858-68.

37. Welte T, Miravittles M, Hernandez P, Eriksson G, Peterson S, Polanowski T, et al. Efficacy and tolerability of Budesonide/formoterol added to tiotropium in patients with chronic obstructive pulmonary disease. Am J Respir Crit Care Med. 2009:180:741-50

38. Sharafkhaneh A, Southard JG, Goldman M, Uryniak T, Martin UJ. Effect of budesonide/formoterol pMDI on COPD exacerbations: a double blind randomized study. Respir Med. 2012;106:2257-268.

39. Vogelmeier CF, Bateman ED, Pallante J, Alagappan VK, D'Andrea P, Chen $H_{\text {, }}$ et al. Efficacy and safety of once-daily QVA149 compared with twice-daily salmeterol-fluticasone in patients with chronic obstructive pulmonary disease (ILLUMINATE): a randomized, double-blind, parallel group study. Lancet Respir Med. 2013;1:51-60.

40. Wedzicha JA, Decramer M, Ficker JH, Niewoehner DE, Sandstrom T, Taylor $A F$, et al. Analysis of chronic obstructive pulmonary disease exacerbations with the dual bronchodilator OVA149 compared with glycopyrronium and tiotropium (SPARK): a randomized, double-blind, parallel group study. Lancet Respir Med. 2013:1:199-209.

41. Vincken W, Aumann J, Chen H, Henley M, McBryan D, Goyal P. Efficacy and safety of coadministration of once-daily indacaterol and glycopyrronium versus indacaterol alone in COPD patients: the GLOW6 study. Int J COPD. 2014;9:215-28.

42. Singh D, Nicolini G, Bindi E, Corradi M, Guastalla D, Kampschulte J, et al. Extrafine beclomethasone/formoterol compared to fluticasone/salmeterol combination therapy in COPD. BMC Pulm Med. 2014;14:43.

43. Donohue JF, Maleki-Yazdi MR, Kilbride S, Metha R, Kalberg C, Church A. Efficacy and safety of once-daily umeclidinium/vilanterol 62.5/25 mcg in COPD. Respir Med. 2013;107:1538-46.

44. Celli B, Crater G, Kilbride S, Metha R, Tabberer M, Kalberg C, et al. Once-daily umeclidinium/vilanterol 125/25 mcg in COPD: a randomized, controlled study. Chest. 2014;14585:981-91. 